\title{
On the Localization of Criminal Reconciliation System in China
}

\author{
Yu Ke, Yao Tianchong \\ Northeastern University \\ Shenyang, China
}

\begin{abstract}
The criminal reconciliation system is favored by the countries all over the world because of its remarkable value function in the realization of penalty justice and efficiency. Our country has the soil of "localization" of the criminal reconciliation system, but at the same time, because of the influence of economy, traditional culture and concept, it is difficult to localize the criminal reconciliation system as an "import" in our country. This paper attempts to point out the necessity of "localization" of the criminal reconciliation system on the bas is of analyzing the theoretical basis on which the criminal reconciliation system is based, and points out the difficulties encountered in the implementation of the criminal reconciliation system in China. To find a way out to establish a criminal reconciliation system adapted to China's national conditions.
\end{abstract}

Keyword-Criminal reconciliation; localization; judiciary; Restorative justice

\section{INTRODUCTION}

The idea of criminal reconciliation coincides with the traditional Chinese thought of "harmony". If the traditional judicial model can be called "adversarial justice", the rise of the criminal reconciliation system means that a new judicial model based on cooperation and consultation is gradually emerging. This model can be called the "private cooperation model'[1]. The purpose of this paper is to explore the problems and solutions to the localization of criminal reconciliation.

\section{OVERVIEW}

The so-called criminal reconciliation means that during the course of the criminal proceedings, the victims and the perpetrators conciliate by means of confession, apology, compensation, etc. The special organ of the state no longer investigates the criminal responsibility of the offender or deals with the case with a lighter punishment, the purpose of which is to restore the harmonious relationship between the offender and the victim, and to rehabilitate the criminal and return to society.

\section{A. Distinction Between Criminal Reconciliation and Private}

Strictly speaking, "private" is not an accurate legal term, and "private" generally refers to the settlement of disputes between the parties through private consultation. From the point of view of criminal law system, our country holds a negative attitude towards "private" behavior. But the criminal reconciliation must require the litigants to be presided over by a specific conciliator in the institution stipulated by the law, and the state holds a positive attitude towards the result of mediation.

\section{B. Distinction Between Criminal Reconciliation and Mediation}

Mediation is a judicial system in civil litigation in China. It is widely used in civil litigation cases and is carried out by the judicial organs on their own initiative. In criminal proceedings, the system of criminal reconciliation is widely applied to criminal cases unless it is not appropriate in individual cases. Generally, when the perpetrators and the victims agree, the criminal reconciliation system is carried out by the specialized organs in accordance with their functions and powers. The system of criminal reconciliation is more respectful of the will of the parties concerned.

\section{Distinction Between Criminal Reconciliation and Plea Bargaining}

The contract subject of plea bargaining is the prosecutor and the defendant, which reflects the balance between public interest and personal interest. The applicable option is in the hands of the prosecution organ, and the result does not generally include compensation to the victim[2]. But the criminal reconciliation takes place between the victim and the offender, usually under the condition that the facts of the case are clear and the responsibility is clear, the victim and the offender decide voluntarily whether it is applicable or not. The outcome of the negotiations usually includes adequate compensation to the victim.

\section{InVESTIGATION OF THE THEORETICAL BASIS}

Throughout the world's criminal reconciliation system, its establishment and development are the product of the continuous progress of the concept of national human rights and the rule of law, and the subversion and development of the traditional adversarial criminal law concept. Its theoretical basis is the theory of "restoring justice", the modest theory of criminal law and the spirit of contract.

\section{A. The Theory of Restorative Justice}

The theory of restoring justice is a subversion of the traditional retribution theory of criminal law. Unlike traditional retribution penalties, which are intended to address "what laws have been violated", "who has violated it "and "what penalties should be imposed on those who violate the law", The theory of restoring justice is more concerned with "who has been harmed by the crime", "what kind of loss he has suffered", "how they can recover this loss"[3]. while ensuring that the victim is fully compensated. Considering that the victimizer has 
the right to return to the society, the theory of restoration justice is produced in the interests of balancing and restoring the relationship between the perpetrator, the victim and the society.

\section{B. The Modesty Spirit of Criminal Law}

Because the punishment of criminal law is the most severe, the implementation of other laws needs the protection of criminal law, so criminal law is in the position of safeguard law in the legal system. Criminal law can be applied only when other sanctions, such as moral, administrative, and other legal means, are not sufficient to suppress violations. At present, China is in the period of social contradictions gathering and highlighting. If most of the social contradictions enter the judicial process in the form of cases and are regulated by the state's coercive power, the judicial organs are not only overburdened, but also not conducive to the resolution of social contradictions. Finally, it is harmful to social harmony and stability. In this case, criminal reconciliation deals with cases in the form of consultation and cooperation, which meets the needs of the theory of modesty of criminal law in judicial practice.

\section{The Spirit of Freedom of Contract}

In the process of reconciliation, the victim and the perpetrator determine the range of punishment through equal consultation, judicial personnel examine the crime from an equal angle of view, not only can the victim obtain compensation, It also enables perpetrators to re-recognize the harm of crime and the value of the law, so as to better reflect justice. The system of criminal reconciliation is to creatively apply the spirit of freedom of contract to the criminal justice. It is a contract reached by both parties on the peaceful settlement of the case.

\section{NECESSITY OF "LOCALIZATION” OF CRIMINAL RECONCILIATION SYSTEM}

The vitality of criminal reconciliation system is rooted in the experience of Chinese social life, and its practical development in China also shows that the emphasis on harmony, the emphasis on judicial realism of the criminal law system can promote the development of Chinese society. Therefore, it is necessary to discuss the system of criminal reconciliation in combination with China's criminal practice.

\section{A. The Need to Protect the Legitimate Interests of the Perpetrators and to R-socialize them}

Prompt action is a basic need of perpetrators in the process of criminal justice. The rapid operation of investigation, prosecution and trial can greatly reduce the worries of the perpetrators about their future and fate, enable them to realize their own mistakes as soon as possible, and start their efforts to reintegrate into society as soon as possible. The criminal reconciliation system adapts to this need, so that the victimizer (especially the juvenile offender) can determine their judicial fate in time and reduce the influence of uncertainty in the criminal justice process. At the same time, through face-to-face consultations and discussions between the perpetrator and the victim, the perpetrator has a profound understanding of the serious consequences of his or her actions, thereby encouraging them to admit their mistakes in good faith, to take the responsibility proactively and to resocialize more naturally. This effect is difficult to achieve by strict judicial process and corrective measures.

\section{B. The Need to Maximize the Interests of the Victims}

Japanese scholar Haruko Nishimura believes that "restoring the rights and needs of victims is the first priority in dealing with crime"[4]. The process of criminal reconciliation reduces the disputes over the attribution of responsibility, and because the content of compensation in the settlement agreement is reached through voluntary negotiation among the parties, it has a stronger executive power, which can ensure the timely compensation for the victims' losses. Reconciliation also weakens the victim's retribution emotion, reduces the conflict degree of both sides, and helps to restore the normal social relations between the two sides. In short, criminal reconciliation enhances the victim's status in litigation and gives the victim an opportunity to personally participate in conflict resolution.

\section{The Need to Improve Judicial Efficiency and Save Judicial Resources.}

The high efficiency of the criminal reconciliation system means that it consumes less judicial resources and obtains the ideal substantive goal, which is advocated by the theory of law and economics. The efficiency of the criminal reconciliation system is manifested in two aspects: one is to directly realize the efficiency of litigation in individual cases. The efficiency of the criminal reconciliation system is manifested in two aspects: one is to directly realize the efficiency of litigation in individual cases. In judicial practice, there are a large number of minor criminal cases. If both sides agree to settle, the judicial organs only need to examine and confirm whether the settlement agreement is legal and voluntary, thus realizing the maximum benefit of the case litigation. The second is to realize the overall benefit of justice. Criminal reconciliation can effectively solve a large number of minor criminal offences, so that the judicial organs can optimize the allocation of judicial resources, concentrate human, material and financial resources to crack down on major criminal offences, and reduce the loss of public interest.

\section{The Need of Building a Harmonious Society}

Harmonious society requires saving judicial costs, improving judicial efficiency and realizing the optimal allocation of judicial resources in the whole criminal justice activities. Therefore, under the background of building a harmonious society, criminal reconciliation must adapt to the requirements of the development of the times. So that the criminal justice resources are allocated reasonably and the judicial benefits are maximized. In addition, it must realize social fairness and justice as far as possible safeguard the legitimate rights and interests of both parties, so as to create a stable and peaceful social environment so that both individuals and society can achieve sustainable development.

\section{The Difficulties Faced by the Criminal RECONCILIATION SYSTEM IN CHINA}

The earliest practice of China's criminal settlement system was that the Beijing Chaoyang District people's Court applied the out-of-court settlement system to criminal cases. Since then, 
Shanghai, Zhejiang, Anhui and other places have formulated the normative documents of the criminal reconciliation system, and achieved certain social effects. At the same time, we should also see that the criminal reconciliation system is faced with the dual dilemma of theory and practice.

\section{A. Theoretical Dilemmas}

First, conflict with the statutory principle of crime. In accordance with the statutory principle of crime, the criminal act of the perpetrator must be subject to criminal punishment, and the implementation of the criminal reconciliation system will result in impunity and impunity, which impairs the certainty of the crime and the penalty.

Second, it conflicts with the principle of equality before criminal law. The principle of equality before criminal law requires that all persons be treated fairly before criminal law. However, the criminal reconciliation may lead to the situation that the offender with certain economic strength can be relieved or even exempted from the criminal law through economic compensation, while the offender without economic strength will bear the criminal responsibility. The amount of wealth becomes an important factor to determine the penalty, and it is easy to abuse the right of penalty.

Thirdly, it conflicts with the principle of crime, responsibility and punishment. The principle of criminal liability and penalty adaptation requires that the criminal responsibility and punishment of the offender should be adapted to the criminal act, and the criminal reconciliation may exempt the offender from criminal responsibility and be not subject to criminal punishment, thus weakening the preventive and punitive functions of the criminal law [5].

\section{B. Practical Dilemmas}

\section{1) Functional dissimilation-The breeding of corruption under the intervention of public power}

First of all, from the point of view of judicial practice of criminal reconciliation, the court actively promotes peace, forcing both parties to reconcile, which means the deviation of the basic function of the public power organs in the fight against crime.

Secondly, the degree of preference for the penalty of the offender should be judged according to the legal penalty range and the overall situation of the case. If we blindly deal with the scheme required by the perpetrator, the penalty provisions will be virtually empty, and the criminal reconciliation will evolve into a "transaction" of money which can be measured according to the penalty required by the perpetrator, and it will inevitably deviate from the concept of rule of law.

\section{2) Value unbalance-The function of Criminal Reconciliation is difficult to graspeffectively}

In terms of content, the settlement agreement carries both objective and subjective factors. For judicial organs, the objective factors such as material loss and compensation are easy to measure and grasp because of their externalities, but subjective factors such as confession of guilt and repentance are difficult to measure and judge because of their inherent nature. The premise of criminal reconciliation is sincere confession and repentance on the part of the perpetrator, but we cannot tell from the signed and sealed settlement agreement whether the offender is truly repentant or not, the victim is a kind of helpless choice based on the real hardship or the real understanding of the victimizer. Therefore, it is difficult to effectively grasp the situation of criminal reconciliation and the matching of various interests.

In this situation, the criminal reconciliation system designed for repentance, compensation, understanding, and lenient multiple procedures may eventually evolve into a single procedure of compensation and exemption in practice. As a result, the penalty substitution function is difficult to realize, so it is difficult to escape the question of "money person patent".

3) Lack of system-The validity and maneuverability of Criminal Reconciliation are difficult to guarantee

On the one hand, the lack of a national compensation system. The voluntary nature of the settlement agreement is the basic condition for the judiciary to consider whether to be lenient. Because China has not established the national compensation system at present, the victims are easily forced to settle with the perpetrators because of the difficulties in their lives after being harmed by the criminal acts, so as to obtain economic compensation as soon as possible, thus affecting the voluntary nature of the reconciliation.

On the other hand, lack of supervision and restriction mechanism. Since criminal reconciliation is based on dialogue and consultation, compared with ordinary criminal proceedings, criminal reconciliation procedures lack attention to the principle of due process. Once the way of reconciliation can bring vital benefits to the parties, the criminal reconciliation may become a new way to interfere with the administration of justice and a new window of judicial corruption.

\section{Some Suggestions on Perfecting the System of CRIMINAL RECONCILIATION}

The result of the criminal reconciliation system tends to the non-punishment of criminal justice and the non-imprisonment of criminal execution, which will inevitably impact the authority of the traditional criminal law to a certain extent. It is therefore necessary to strengthen the examination and supervision of the process of criminal reconciliation. Only by perfecting the supporting punishment mechanism of criminal reconciliation and establishing the supporting system of state compensation can we effectively deal with conflicts and dilemmas and give full play to the functions of the system of criminal reconciliation.

\section{A. Improving Continuous Measures to Investigate the Offender's Attitude Towards Repentance}

The purpose of the offender's sincere repentance is to reduce the personal danger of the offender, so the investigation of whether the offender is sincere repentance should not be confined to the process of criminal reconciliation. Because the perpetrators, in order to avoid severe punishment, can't avoid the possibility of making a show. The investigation of the attitude of the offender should continue until a period after the criminal reconciliation has been reached. If the offender still commits a criminal act, the procuratorial organ has the power to revoke the criminal reconciliation agreement and to review and prosecute the offender again. 


\section{B. Strengthening the Legal Supervision of Criminal Reconciliation}

The implementation process and outcome of the settlement agreement in the criminal reconciliation system must be subject to the supervision and review of the national judicial authority. The criminal settlement is initiated voluntarily by the party concerned and presided over by an independent third party who has nothing to do with the criminal dispute, but this does not mean that the judicial right of the state has lost the supervision of the criminal reconciliation. First, the national judiciary should review the legality of the initiation of the criminal reconciliation process to ensure that the criminal reconciliation is initiated on the voluntary basis of the victim and the legality of the applicable conditions and scope of the criminal reconciliation system. Secondly, the state judicial organs should supervise the legality of the criminal reconciliation procedure to ensure the operability of the settlement agreement. Finally, the contents of the settlement agreement should be confirmed and given legal effect in the name of the national judiciary.

\section{Perfecting the Punishment Mechanism of Criminal Reconciliation}

At present, there are limited kinds of non-custodial punishment in our country, which makes the criminal reconciliation system difficult to carry out effectively. Therefore, there is a need to enrich the variety of non-custodial sentences and to improve alternative punishment measures. By increasing labor compensation, exchanging stolen goods, community service, compensatory public welfare labor and other non-penal measures, we can create conditions for the application of the criminal reconciliation system and make the application of criminal reconciliation have maneuverability [6].

\section{Establishing National compensation system}

In the aspect of victimizer, for some cases which accord with the condition of criminal reconciliation, the victim can not get full compensation because of the poor condition of the offender's family. At this time, in order to ensure the equality of criminal reconciliation, the state can provide compensation. In the aspect of the victim, it is necessary to carry on spiritual comfort to the victim. Compensation funds can be obtained through the following channels: first, state financial support; second, part of the fines and confiscated property; third, social donations[7]. Only with the perfect national compensation system as the backing, the criminal reconciliation system to resolve hatred, restore social relations and other multiple values will not be submerged by the economic loss of the monolithic value.

\section{CONCLUSION}

Although the criminal reconciliation system originated from foreign countries, since the new criminal law was formulated, China has begun to use the criminal reconciliation system to resolve criminal disputes. The application of the criminal reconciliation system in our country is worthy of recognition, but also needs to be improved. We should treat the establishment of the criminal reconciliation system in our country rationally and perfect the criminal reconciliation system through the feedback in the judicial practice.

\section{REFERENCE}

[1] Chen Guangzhong. The theoretical basis and Judicial Application of Criminal Reconciliation [J]. People's Procuratorate 2006 (10): 5-7. (In Chinese)

[2] Cheng, Zhuang Xue long. Reconsideration of some problems in the process of Localization of Criminal Reconciliation system [J]. On the Rule of Law (Journal of Shanghai University of political Science and Law) 2009,24 (03): 43-50. (In Chinese)

[3] Peng Gang. On the Dilemma and the way out of the Localization of Criminal Reconciliation [J]. Journal of Daqing normal University 2010, 30 (05): 45-49. (In Chinese)

[4] Wang Junyi. The predicament and outlet of Criminal Reconciliation in China [D]. South China University of Technology,2010. (In Chinese)

[5] Yu Wenbo. The dilemma and resolution of the system of criminal reconciliation [J]. Rule of Law and Society 2018 (19): 25-26. (In Chinese)

[6] Jiang Shuhua, Ren Jianhua. The Construction of Local Criminal Reconciliation Model [J]. Shandong Social Science: 2013 (11): 184-1888.(In Chinese)

[7] Crown Prince. An Analysis of Criminal Reconciliation and its Localization Construction [J]. Journal of Sichuan University of Arts and Sciences,2013, 23 (04): 16-20. 